\title{
Does Ease of Communication InCREase Trade? COMmONality OF LANGUAGE AND BILATERAL Trade
}

\author{
by
}

\author{
William K. Hutchinson
}

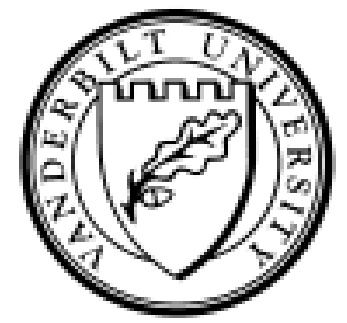

Working Paper No. 02-W17

June 2002

\section{DEPARTMENT OF ECONOMICS \\ VANDERBILT UNIVERSITY \\ NASHVILLE, TN 37235}

www.vanderbilt.edu/econ 


\title{
Does Ease of Communication Increase Trade? Commonality of Language and Bilateral Trade
}

\author{
William K. Hutchinson \\ Department of Economics \\ Vanderbilt University \\ Nashville, TN 37235 \\ e-mail william.hutchinson@vanderbilt.edu
}

June, 2002

JEL Codes: F1, J1

Key Words: Trade, Gravity, Language

Draft: Not to be quoted without permission from the author. 


\begin{abstract}
Gravity model explanations of trade volumes frequently include dummy variables to account for the commonality of language among trading partners. In this paper we use a data set for the number of people in a country who speak English as a first language or English as a second language (Crystal, 1997) as an indicator of the ease with which trade with the United States occurs. Controlling for commodity fixed effects we use SITC three digit industry data centered on 1995 United States bilateral trade with 33 countries to determine the effect of the degree of language commonality on bilateral trade. Both English as a first language and English as a second language are found to be more important for exports than for imports. This is true for all three digit industries as well as when the specific industry groups identified in Rauch (1999) are considered
\end{abstract}


Which products are traded among countries and the volume of trade in these products are two questions that have captured the attention of international trade economists for more than two centuries. Ricardo, Mill, Heckscher, Ohlin, and others have focused on determining which products would be exported and which would be imported. In the 1960s interest shifted to determining the volume of trade and the work of Tinbergen (1962) and Linnemann (1966) are early examples of such studies. Models of these two aspects of trade, however, are quite different. Models that determine which products are traded focus on the relative factor endowments of countries, whereas models of the volume of trade focus on the relative economic size and well being of countries.

We focus on the determinants of the volume of trade, which are usually captured in the framework of a gravity model. If one assumes identical and homothetic preferences, then in a gravity model the relative economic size of trading partners determines the potential volume of trade. Economic size is generally measured by some combination of country GDP, population, or per capita GDP. In a gravity model, the difficulty associated with the exchange of goods between trading partners diminishes the potential volume of trade relative to that implied by their economic size in a frictionless world. Theory indicates that a country demands goods in the world market in direct proportion to its share of world income, controlling for the difficulty of obtaining those goods from another country. The stage of a country's development may as well impact the volume of trade independently of the absolute size of its GDP. Degree of development is usually measured by per capita income. ${ }^{1}$

\footnotetext{
${ }^{1}$ Per capita income also reflects the capital labor ratio in a country, assuming identical constant returns to scale production technology in all countries. If one assumes increasing returns to scale technology, then a higher per capita income may result from larger size as well as a higher capital labor ratio, depending on the nature of the increasing returns to scale.
} 
Impediments to trade such as transport costs, tariffs, legal differences and a group of factors that generate positive transactions costs diminish the volume of trade that takes place between any two countries. A major barrier to trade is difficulty in communication. Because people in different countries as a rule speak different languages, exchange of goods may be impeded by costs associated with surmounting language barriers. We are concerned with the effect of language on the volume of trade, i.e., the commonality or lack of commonality of language for residents of trading partners. In particular, we shall examine the importance of English speakers in a trading partner country in determining that country's volume of trade with the United Sates.

We shall proceed by discussing in section 2 how the existing literature provides the theoretical underpinnings for our analysis, by presenting the data in section 3 , and by discussing the empirical findings in section 4 . We shall conclude with a brief summary of our findings and a consideration of avenues for future research.

\section{The Basic Approach}

Theoretical foundations for the gravity model are surveyed in Frankel (1997), Baier and Bergstrand (2001), and elsewhere in this issue by Feenstra (2002). Therefore, we shall provide only the necessary background to motivate our research. Early applications of the gravity model were viewed with skepticism, to say the least, by those who used more structurally based models to analyze international trade. Explaining the volume of trade is sometimes more useful than explaining the factor content of trade or testing the Heckscher-Ohlin model. The work of Anderson (1979) and Bergstrand $(1985,1989)$ provided a sound microeconomic foundation for gravity model analysis of trade flows. ${ }^{2}$ The result has been wider acceptance and more frequent

${ }^{2}$ Helpman and Krugman (1985) derive the gravity model within an imperfect competition model. 
application of the gravity model to questions regarding the volume of international trade among countries.

Initially, the gravity model was used to explain aggregate bilateral trade volumes, but more recently this model has been applied to disaggregated data to determine if particular product groups are impacted differentially by the factors that determine the volume of trade. ${ }^{3}$ The general equilibrium theoretical framework used by Anderson (1979), Bergstrand (1985 and 1989), and Gould (1994) derives export and import flows as a function of the standard trading partner variables: GDP and either population or per capita income. Additionally, the general equilibrium model introduces relative prices, including tariffs, and a vector of variables that either increase or decrease the cost of conducting international trade. For example, distance between trading partners, contiguity of trading partners, the commonality of language, culture and laws, whether the trading partners belong to a preferential trading area (PTA) or to a common PTA. Rauch (1999) develops a theory of networks that explains how many of these factors impact the volume of bilateral trade. ${ }^{4}$

This article focuses on the importance of the commonality of language in facilitating the flow of international trade. Many gravity model applications have used dummy variables to capture the benefits of trading partners speaking a common language. The usual result is that a common language results in greater trade volume between two countries. ${ }^{5}$

${ }^{3}$ See for example Bergstrand (1989, 1990), Gould (1994), Feenstra, Markusen and Rose (1998) Dunlevy and Hutchinson (1999), Hutchinson and Dunlevy (2001), Baier and Bergstrand (2001). ${ }^{4}$ Head and Ries (1998), Gould (1994), Dunlevy and Hutchinson (1999) and Hutchinson and Dunlevy (2001), Rauch and Trindade (2002), and Wagner, Head, and Ries (2002) address the effects of immigrants and the formation of networks that enhance the volume of trade between the host country and the country of origin. Frankel, Stein and Wei (1998) provide an excellent review and analysis of the other major factors within the context of a gravity model.

${ }^{5}$ Frankel (1997, pp. 74-76) reviews the literature on this topic. Chiswick and Miller (1998) use a language index to explain the relative difficulty for immigrants from particular countries become integrated into the United States economy. 
Boisso and Ferantino (1997) construct a measure of linguistic similarity based on the proportion of a population that speaks a particular language as a first language. The index approximates the probability that two randomly chosen people in an importing and exporting country speak the same language. Their measure of linguistic distance did not significantly affect the level of trade between two countries nor did it affect the over all level of trade.

Hutchinson (2001) uses an index, developed by Chiswick and Miller (1998), to extend Gould (1994) to analyze the importance for trade flows that results from the difficulty for a native English speaker in learning a foreign language. Chiswick and Miller (1998) develop a "linguistic distance" index that indicates the relative difficulty of learning various foreign languages if one is a native English speaker. Controlling for the standard gravity model variables, including the stock of migrants from a particular country, Hutchinson finds that United States bilateral trade between 1970 and 1986 was lower with a country that had a dominant language which was more difficult to learn. This effect was especially important for U. S. imports of consumer manufactures.

Here we exploit a new source of information regarding the commonality of language. David Crystal, a linguist, focuses on the growth and spread of the English language to various other countries in the world. For a set of 74 countries Crystal (1997) estimates the number of people in each country who speak English as their first language and the number who speak English as their second language. We use these data in a gravity model to estimate the effect on bilateral trade of the proportion of the population in a country who speak English as a first or as a second language. We hypothesize that the larger the proportion of the population who speak English as a first language the greater the volume of bilateral trade with the United States. The same should be true for the proportion who speaks English as a second language. 
A persistent difficulty of working with the gravity model is the problem of specification error or the omitted variable bias that is very difficult to avoid. Matyas $(1997,1998)$, Cheng and Wall (2001) and Pakko and Wall (2001) have raised serious econometric questions regarding the estimation of gravity models. The standard assumption has been that countries were assumed to be homogeneous, except for distance, contiguity, common language etc. However, one cannot be sure what distance or dummy variables for these other effects are actually measuring in the gravity model context. Countries are heterogeneous as are products and at different points in time both may behave differently. Estimation of aggregate trade flows among countries must account for country specific effects along with time specific effects if pooled or panel data are used. If disaggregated data are used, then one must control for commodity specific effects to prevent specification error. A country fixed effect model does not allow one to measure the effect of distance, contiguity, common language, or any other variable that is unchanging relative to a country with respect to time. As discussed below, estimations in this paper will account for heterogeneity bias to the extent that is possible.

We estimate the gravity model in equation (1) where $T_{i j}$ denotes the bilateral trade flow (1) $T_{i j}=\gamma_{i}+\beta_{1} G D P U S * G D P_{j}+\beta_{2} P O P U S * P O P_{j}+\beta_{3} E n g 1+\beta_{4} E n g 2+\beta_{5} D i s \tan c e+u_{i j}$ (export or import) of product $i$ between the United States and country $j . \quad \gamma_{i}$ is the commodity specific characteristic variable that captures the heterogeneity among products. We are only looking at one year so no time specific variables are necessary. GDPUS denotes GDP for the United States and $G D P_{j}$ is the dollar value of GDP for the corresponding trade partner. POPUS and $P O P_{j}$ are analogously population for the United States and the corresponding trade partner. Eng 1 and Eng 2 are the percentage of the total population that speaks English as a first language or English as a second language, respectively. Distance is the great circle distance between the 
capitals of trade partners and Washington, D.C.. The larger the combined GDP of the trading partners, then the larger one would expect trade to be, either exports or imports. The same is true for population. We hypothesize that $\beta_{1}, \beta_{2}, \beta_{3}, \beta_{4}>0$ and $\beta_{5}<0$.

\section{Data}

The English language data are derived from Crystal (1997) and are estimates of the proportion of people in each of 74 countries who speak English as their first language, Eng 1, or as their second language, Eng 2. We will use only 33 of these countries as a result of the availability of trade data. A list of the countries is provided in Appendix A along with data for Eng 1 and Eng 2..6

Trade data are from the World Bank and are the average of either United States exports or United States imports at the SITC three digit level for the years 1994, 1995 and 1996. The GDP data and population data are from the IMF IFS-CD and are also the average for the years 1994, 1995, and 1996. Distance is the great circle distance of Washington, D.C. from the capitals of countries and the data were obtained from the trade resources website maintained by Raymond Robertson. ${ }^{7}$ We have used averages for these three years, centered on 1995, to avoid any undue single year effect that might result from using only 1995 data.

We will also use Rauch's product classification data, which classifies three digit industries according to whether the products are homogeneous and sold on an organized exchange, reference priced, or differentiated. Rauch does not classify all three digit industries so

\footnotetext{
${ }^{6}$ One was added to the number of people who were reported to speak English as either their first or second language so that differences in logarithms could be used to calculate the proportions when the estimated number of people was zero. The resulting proportion is zero. ${ }^{7}$ http://www.macalester.edu/research/economics/PAGE/HAVEMAN/TradeResources/Data/ Gravity/dist.txt.
} 
the number of industries that will be considered when these data are used is considerably smaller than otherwise.

All data are entered in logarithmic form as is customary given the theoretical foundations of the gravity model. As a result, each of the coefficients may be interpreted as an elasticity.

\section{Results}

Estimating equation (1) allows one to observe the effects of the commonality of language on trade. The income, population, and distance variables in Table 1 have the expected signs, indicating that as the combined size of two trading partners increases a greater volume of trade occurs. ${ }^{8}$ On the other hand, the volume of trade between the U.S. and a country declines as the distance between the two increases. The effect of distance on exports appears to be greater than the effect of distance on imports. ${ }^{9}$

Results in the first two columns indicate that both the proportion of the population that speaks English as a first language and the proportion that speaks English as a second language have a positive influence on exports and imports. That is, controlling for a country's income and total population as well as how distant it is from the U.S., both exports and imports are greater for countries that have a higher proportion of the population who speak English as a second language.

\footnotetext{
${ }^{8}$ Since we are examining only one year, all of the variation in the income and population variables is introduced by other countries. Using the log of the product of United States GDP and the foreign GDP and the logarithm of the product of United States population and the foreign population provides the theoretically indicated size effect for trade.

${ }^{9}$ We are aware of the issues raised by Grossman (1998) relating to interpretations of the distance coefficient. Our estimates are similar to those in the literature, but as many have discovered the inclusion of trade enhancing variables such as communication, represented by Eng 1 and Eng 2, reduces the distance coefficient. See Portes, Rey and Oh (2001) and in this issue of the Journal Loungani, Mody and Razin (2002) for discussions of this issue.
} 
These results imply that, other things the same, a country that has a ten percent higher proportion of people who speak English as a first language would receive 1.3 percent more exports from the U.S. and send 1.3 percent more products to the U.S.. However, a country that has a ten percent higher proportion of people who speak English as a second language would receive 1.7 percent more exports from the U.S. and send 2.3 percent more products to the U.S.. The proportion of the population that speaks English as a second language is 1.3 times more important for exports and are 1.75 times more important for imports than is the proportion that speaks English as a first language.

A possible explanation for the greater importance for the proportion who speak English as a second language is that these are the people who devoted resources to learning English. That is, those who devote resources to learn English do so because they expect to earn a positive return from their investment in the form of greater commerce with the United States or other English speaking countries.

Equation (1) accounts for the size effect of two countries on the volume of trade between the two, but it does not account for the level of development of the various countries. To account for the effect of development we estimate equation (2), where per capita GDP replaces population as a determinant of trade. Equations (1) and (2) are mathematically equivalent, but one may draw different interpretations from them.

(2) $T_{i j}=\gamma_{i}+\beta_{1} G D P U S * G D P_{j}+\beta_{2} G D P_{j} / P O P_{j}+\beta_{3} E n g 1+\beta_{4} E n g 2+\beta_{5} D i s \tan c e+u_{i j}$

Estimation results for equation (2) appear in columns 3 and 4 of Table 1 . The coefficient on the economic size variable, GDPUS* GDP, , equals the sum of the coefficients on GDP and population from the estimation results of equation (1), as theory indicates it should. ${ }^{10}$ However, ${ }^{10}$ See Frankel (1997) chapter 4 for a discussion of the relationship between he specification in equation (1) and that in equation (2). 
the negative coefficient for GDP per capita indicates that trade, both exports and imports, was greater between the United States and countries with lower levels of development, controlling for economic size, distance, and English speaking population. None of the other coefficients are changed as a result of the per capita income specification in equation (2).

United States exports to these countries increased less than proportionately with respect to the economic size (Column 3) of a country, which is reflected by the coefficient on GDP of 0.71 that is significantly less than one. However, United States imports from these countries increased more as a result of an increase in the size (Column 4) of the country which is reflected by the coefficient on GDP of 0.93 , which is only slightly less than one.

All of these countries except Nepal were once British colonies or under British control. One could argue that Nepal's geographic location exposed it to a great deal of British legal and cultural influence. Thus, we believe that the bias sometimes attributed to colonial linkages for particular countries is limited in this instance.

When one controls for industry fixed effects, Table 2, the coefficients are virtually the same as in the original regression results in Table 1. This implies that there are no significant industry fixed effects that were biasing the initial results. All the coefficients are slightly larger than in the initial regressions and the standard errors are smaller. When per capita GDP is accounted for in columns 3 and 4, the results are the same. The interpretation of these coefficients, including the relative importance of the proportion of the population that speaks English as a second language, remains unchanged when we account for commodity fixed effects.

\section{Product Groups}

Hutchinson (2001) finds that language distance affected trade in consumer manufactures more than it did producer manufactures. Rauch (1999) creates a commodity classification which 
determines for a large number of SITC three digit industries whether commodities are sold in an organized exchange market, in a reference price type of market, or if the goods are differentiated products. When Rauch and Trindade (2002) consider the effect of relative Chinese immigrant stocks on trade, they find that larger combined stocks of Chinese immigrants results in greater trade in differentiated products. We shall examine the subset of commodities in our data set for which Rauch's classifications correspond in an attempt to determine if language commonality differentially impacts trade with particular types of goods..

Regression result reported in columns 1 and 2 of Table 3 indicate that the coefficients for the variables were the same size as in columns 1 and 2 of Table 1 . The proportion of the population speaking English as either a first or as a second language was important only for exports of the goods classified by Rauch. ${ }^{11}$ Results for exports when the level of development is considered in columns 3 and 4 of Table 3 are the same as in Tables 1 and 2. The level of development has the same negative effect on exports and imports for the Rauch sample as for the larger sample. In this sample of products, the proportion who speak English as a first language has a larger effect on imports, unlike the results for the larger sample reported in Tables 1 and 2.

Results in Table 4 indicate that the United States tended to export less reference priced good to these countries but relatively more differentiated products. There does not appear to be any significance for either product classification with regard to imports. Results for trade with countries relative to the proportion of the population who speak English as a first language and the proportion who speak English as a second language do not change when one accounts for product categories and interaction terms as well.

\footnotetext{
${ }^{11}$ Due top the limited number of industries classified by Rouch, the sample size decreases substantially.
} 
Trade with countries relative to the proportion of the population that speaks English as a first language and the proportion who speak English as a second language does not change when one accounts for product heterogeneity of exports. ${ }^{12}$ It is the case that the United States exports more to those countries with larger proportions of those who speak English as a second language. At the same time, United States imports of goods classified by Rauch are unaffected by the proportion of the population in the exporting country that speak English as either a first or as a second language.

\section{Conclusion and Ideas for Future Work}

The proportion of the population that speaks English is a significant factor for both exports and imports between the United States and these 33 countries. Controlling for GDP, population, and distance, the proportion who speak English as a second language is more important than the proportion who speak English as a first language for stimulating trade with the United States. Moreover, having a large portion of the population who speak English is more important for exports from the United States than it is for imports into the United States from these countries. A ten percent increase in the proportion who speak English as a second language has a larger impact on trade than a ten percent increase in the proportion who speak English as their first language.

We conjecture that the stronger results for English as a second language relative exports and imports reflects the impact of those involved in commercial activity in these countries where a large proportion of the indigenous population has acquired English as a second language in order to enhance their trade with the United States and other English speaking countries. Thus, controlling for size, distance and the proportion of the population speaking English as a first

${ }^{12}$ This result is from regressions not reported, where the two types of English speakers were interacted with the types of products. 
language, the larger the proportion who speak English as a second language the larger are exports and imports.

If the traded products are classified as being traded on organized exchanges, as reference priced goods, or as differentiated products as Rauch (1999) did, then speaking English was important only for export from the Untied States. Moreover, product groups behaved differently when considered as exports than they did when considered as imports. Products traded on organized exchanges and differentiated products were more important for exports, while reference priced goods tended to be less important for exports. ${ }^{13}$ Imports, on the other hand, tended to be greater for reference priced goods, while being lower for goods traded on organized exchanges and for differentiated products. ${ }^{14}$ The indication would be that the United States has a greater tendency to import goods that are reference priced and to export goods that are traded on organized exchanges and goods that are differentiated. This is consistent with the Untied States exports of agricultural goods and differentiated manufactured goods. The relative proportions of the population who speak English either as their first or second language has no differential effect on these product classifications.

The level of economic development for these countries, as measured by the level of per capita income, was negatively related to exports and import. This was true for the total sample as well as the Rauch sample. Thus, controlling for size, distance, proportion speaking English as a first language, and proportion speaking English as a second language, the United States traded less with those countries with higher per capita income.

\footnotetext{
${ }^{13}$ The larger constant term in Table 4, in comparison with Table 3, indicates that the omitted category, goods traded on an organized exchange, had a positive impact on exports. However, the constant is smaller in Table 4 than in Table 3 for imports, indicating that imports of goods traded on organized exchanges were lower.

${ }^{14}$ The coefficients for imports are not statistically significant. However, the coefficient size leads one to believe that these coefficients may have economic significance.
} 
Recent contributions to the international trade literature have raised questions regarding the typical empirical specification of the gravity model. That is, the inclusion of variables that are supposed to capture those elements which either impede or enhance trade between countries, e.g., distance, common language, common border, membership in a preferential trading group, etc., may result in specification error. If variables are omitted that happen to be correlated with variables that are included, then the results attributed to a particular variable may be biased. We estimated a strictly country fixed effects model to compare with the results reported in Tables 1 and 2. The country fixed effects models explained between five and ten percent more of the variation in exports and imports than did equation (1), based on adjusted $R^{2}$. If one compares the root mean squared errors for these models, there are no significant differences between the fixed effects model and either equation (1) or equation (2). Specification issues are an area in which future research may well offer new insights into applications of the gravity model to explaining the volume of international trade. 
Table 1 Regression Results: All Commodities

\begin{tabular}{|c|c|c|c|c|}
\hline $\begin{array}{l}\text { Exogenous } \\
\text { Variable }\end{array}$ & Exports & Imports & Exports $^{\mathrm{a}}$ & Imports $^{\mathrm{a}}$ \\
\hline GDPUS $^{*} \mathrm{GDP}_{\mathrm{i}}$ & $\begin{array}{l}0.39 * * * \\
(26.32)\end{array}$ & $\begin{array}{l}0.53 * * * \\
(21.26)\end{array}$ & $\begin{array}{l}0.71 * * * \\
(40.38)\end{array}$ & $\begin{array}{l}0.93 * * * \\
(36.04)\end{array}$ \\
\hline POPUS*POP ${ }_{i}$ & $\begin{array}{l}0.32 * * * \\
(13.32)\end{array}$ & $\begin{array}{l}0.39 * * * \\
(10.49)\end{array}$ & & \\
\hline GDP Per Capita & & & $\begin{array}{l}-0.32 * * * \\
(13.32)\end{array}$ & $\begin{array}{l}-0.39 * * * \\
(10.49)\end{array}$ \\
\hline Eng 1 & $\begin{array}{l}0.13 * * * \\
(16.50)\end{array}$ & $\begin{array}{l}0.13 * * * * \\
(9.58)\end{array}$ & $\begin{array}{l}0.13 * * * \\
(16.50)\end{array}$ & $\begin{array}{l}0.13 * * \\
(9.58)\end{array}$ \\
\hline Eng 2 & $\begin{array}{l}0.17 * * * \\
(12.54)\end{array}$ & $\begin{array}{l}0.23 * * * \\
(10.17)\end{array}$ & $\begin{array}{l}0.17^{* * *} \\
(12.54)\end{array}$ & $\begin{array}{l}0.23 * * * \\
(10.17)\end{array}$ \\
\hline Distance & $\begin{array}{l}-0.99 * * * \\
(22.72)\end{array}$ & $\begin{array}{l}-0.78 * * * \\
(12.58)\end{array}$ & $\begin{array}{l}-0.99 * * * \\
(22.72)\end{array}$ & $\begin{array}{l}-0.78 * * * \\
(12.58)\end{array}$ \\
\hline Constant & $\begin{array}{c}4.21 * * * \\
(4.88)\end{array}$ & $\begin{array}{l}-1.58 \\
(1.17)\end{array}$ & $\begin{array}{l}10.51^{* * * *} \\
(21.59)\end{array}$ & $\begin{array}{l}6.05^{* * * *} \\
(8.06)\end{array}$ \\
\hline $\mathrm{N}$ & 5610 & 3757 & 5610 & 3757 \\
\hline $\mathrm{R}^{2}$ & 0.36 & 0.36 & 0.36 & 0.36 \\
\hline \multicolumn{5}{|c|}{$\begin{array}{l}\text { a indicates that commodity fixed effects were controlled for using the STATA fixed effects } \\
\text { option. All standard errors were adjusted using the STATA Robust option. t-statistics are in } \\
\text { parentheses and *,**, and } * * * \text { represent significance at the } 10 \%, 5 \% \text { and } 1 \% \text { level, respectively. } \\
\text { The dependent variable is the logarithm of the average of } 1994,1995 \text {, and } 1996 \text { for either U.S. } \\
\text { exports or U.S. imports. GDPUS*GDP equals the logarithm of the product of U.S. GDP and the } \\
\text { foreign GDP. The POPUS*POP is defined analogously to GDPUS*GDP. Eng } 1=\text { the logarithm } \\
\text { of the proportion who speak English as a first language and Eng } 2=\text { the logarithm of the } \\
\text { proportion who speak English as a second language. All variables are in logarithms. }\end{array}$} \\
\hline
\end{tabular}


Table 2 Regression Results for All Commodities With Commodity Fixed Effects

\begin{tabular}{|c|c|c|c|c|}
\hline $\begin{array}{l}\text { Exogenous } \\
\text { Variable }\end{array}$ & Exports & Imports & Exports $^{\mathrm{a}}$ & Imports $^{\mathrm{a}}$ \\
\hline GDPUS $^{*} \mathrm{GDP}_{\mathrm{i}}$ & $\begin{array}{l}0.44 * * * \\
(38.62)\end{array}$ & $\begin{array}{l}0.60 * * * \\
(26.43)\end{array}$ & $\begin{array}{l}0.79 * * * \\
(52.47)\end{array}$ & $\begin{array}{l}1.08 * * * * \\
(42.09)\end{array}$ \\
\hline POPUS*POP ${ }_{i}$ & $\begin{array}{l}0.35 * * * \\
(17.92)\end{array}$ & $\begin{array}{l}0.49 * * * \\
(13.89)\end{array}$ & & \\
\hline GDP Per Capita & & & $\begin{array}{l}-0.35 * * * \\
(17.92)\end{array}$ & $\begin{array}{c}-0.49 * * * \\
(13.89)\end{array}$ \\
\hline ENG 1 & $\begin{array}{l}0.14 * * * \\
(22.62)\end{array}$ & $\begin{array}{l}0.16^{* * * *} \\
(13.69)\end{array}$ & $\begin{array}{l}0.14 * * * \\
(22.62)\end{array}$ & $\begin{array}{l}0.16^{* * * *} \\
(13.69)\end{array}$ \\
\hline ENG2 & $\begin{array}{l}0.19 * * * \\
(16.19)\end{array}$ & $\begin{array}{l}0.25 * * * \\
(11.74)\end{array}$ & $\begin{array}{l}0.19 * * * \\
(16.19)\end{array}$ & $\begin{array}{c}0.25 * * * \\
(11.74)\end{array}$ \\
\hline Distance & $\begin{array}{l}-1.11 * * * \\
(29.18)\end{array}$ & $\begin{array}{l}-0.79 * * * \\
(13.38)\end{array}$ & $\begin{array}{l}-1.11 * * * \\
(29.18)\end{array}$ & $\begin{array}{l}-0.79 * * * \\
(13.38)\end{array}$ \\
\hline Con & $\begin{array}{l}4.38^{* * * *} \\
(6.41)\end{array}$ & $\begin{array}{l}-4.73 * * * \\
(3.78)\end{array}$ & $\begin{array}{l}11.15^{* * * *} \\
(27.94)\end{array}$ & $\begin{array}{l}4.71 * * * \\
(6.79)\end{array}$ \\
\hline $\mathrm{N}$ & 5610 & 3757 & 5610 & 3757 \\
\hline $\mathrm{R}^{2}$ & 0.36 & 0.36 & 0.36 & 0.36 \\
\hline \multicolumn{5}{|c|}{$\begin{array}{l}\text { a indicates that commodity fixed effects were controlled for using the STATA fixed effects } \\
\text { option. All standard errors were adjusted using the STATA Robust option. t-statistics are in } \\
\text { parentheses and } *, * * \text {, and } * * * \text { represent significance at the } 10 \%, 5 \% \text { and } 1 \% \text { level, respectively } \\
\text { The industry fixed effects results are from the STATA fixed effects regressions. The dependent } \\
\text { variable is the logarithm of the average of 1994, 1995, and } 1996 \text { for either U.S. exports or U.S. } \\
\text { imports. GDPUS*GDP equals the logarithm of the product of U.S. GDP and the foreign GDP. } \\
\text { The POPUS*POP is defined analogously to GDPUS*GDP. Eng } 1=\text { the logarithm of the } \\
\text { proportion who speak English as a first language and Eng } 2=\text { the logarithm of the proportion } \\
\text { who speak English as a second language. All variables are in logarithms. }\end{array}$} \\
\hline
\end{tabular}


Table 3 Regression Results for Rauch Industry Classifications (No Fixed Effects)

\begin{tabular}{|c|c|c|c|c|}
\hline $\begin{array}{l}\text { Exogenous } \\
\text { Variable }\end{array}$ & Exports & Imports & Exports $^{\mathrm{a}}$ & Imports $^{a}$ \\
\hline GDPUS $^{*} \mathrm{GDP}_{\mathrm{i}}$ & $\begin{array}{l}0.37 * * * \\
(7.24)\end{array}$ & $\begin{array}{l}0.59^{* * *} \\
(6.83)\end{array}$ & $\begin{array}{l}0.72 * * * \\
(12.53)\end{array}$ & $\begin{array}{l}1.01^{* * *} \\
(11.75)\end{array}$ \\
\hline POPUS $^{*} \mathrm{POP}_{\mathrm{i}}$ & $\begin{array}{l}0.35^{* * *} \\
(4.33)\end{array}$ & $\begin{array}{l}0.42 * * \\
(3.21)\end{array}$ & & \\
\hline GDP Per Capita & & & $\begin{array}{l}-0.35^{* * * *} \\
(4.33)\end{array}$ & $\begin{array}{l}-0.42 * * \\
(3.21)\end{array}$ \\
\hline ENG 1 & $\begin{array}{l}0.10 * * * \\
(3.89)\end{array}$ & $\begin{array}{l}0.17 * * * \\
(4.19)\end{array}$ & $\begin{array}{l}0.10^{* * *} \\
(3.89)\end{array}$ & $\begin{array}{l}0.17 * * * \\
(4.19)\end{array}$ \\
\hline ENG 2 & $\begin{array}{l}0.17 * * * \\
(3.62)\end{array}$ & $\begin{array}{l}0.12 * \\
(1.75)\end{array}$ & $\begin{array}{l}0.17 * * * \\
(3.62)\end{array}$ & $\begin{array}{l}0.12 * \\
(1.75)\end{array}$ \\
\hline Distance & $\begin{array}{l}-0.92 * * * \\
(6.55)\end{array}$ & $\begin{array}{l}-1.00 * * * \\
(5.06)\end{array}$ & $\begin{array}{l}-0.92 * * * \\
(6.55)\end{array}$ & $\begin{array}{l}-1.00 * * * \\
(5.06)\end{array}$ \\
\hline Con & $\begin{array}{l}2.53 \\
(0.84)\end{array}$ & $\begin{array}{l}-1.12 \\
(0.24)\end{array}$ & $\begin{array}{l}9.41 * * * \\
(5.54)\end{array}$ & $\begin{array}{l}6.94 * * * \\
(2.72)\end{array}$ \\
\hline $\mathrm{N}$ & 536 & 338 & 536 & 338 \\
\hline $\mathrm{R}^{2}$ & 0.32 & 0.39 & 0.32 & 0.39 \\
\hline
\end{tabular}

All standard errors were adjusted using the STATA Robust option. t-statistics are in parentheses and $* * *$, and $* * *$ represent significance at the $10 \%, 5 \%$ and $1 \%$ level, respectively. The dependent variable is the logarithm of the average of 1994, 1995, and 1996 for either U.S. exports or U.S. imports. GDPUS*GDP equals the logarithm of the product of U.S. GDP and the foreign GDP. The POPUS*POP is defined analogously to GDPUS*GDP. Eng $1=$ the logarithm of the proportion who speak English as a first language and Eng $2=$ the logarithm of the proportion who speak English as a second language. All variables are in logarithms. 
Table 4 Regression Results: Controlling for Rauch Industry Classifications

\begin{tabular}{|c|c|c|c|c|}
\hline $\begin{array}{l}\text { Exogenous } \\
\text { Variable }\end{array}$ & Exports & Imports & Exports $^{\mathrm{a}}$ & Imports $^{\mathrm{a}}$ \\
\hline GDPUS $^{*} \mathrm{GDP}_{\mathrm{i}}$ & $\begin{array}{l}0.37 * * * \\
(7.38)\end{array}$ & $\begin{array}{l}0.60 * * * \\
(7.00)\end{array}$ & $\begin{array}{l}0.72 * * * \\
(12.66)\end{array}$ & $\begin{array}{l}1.02 * * * \\
(11.84)\end{array}$ \\
\hline POPUS $^{*} \mathrm{POP}_{\mathrm{i}}$ & $\begin{array}{l}0.35^{* * *} \\
(4.29)\end{array}$ & $\begin{array}{l}0.42 * * \\
(3.23)\end{array}$ & & \\
\hline GDP Per Capita & & & $\begin{array}{l}-0.35^{* * *} \\
(4.29)\end{array}$ & $\begin{array}{l}-0.42 * * * \\
(3.23)\end{array}$ \\
\hline ENG 1 & $\begin{array}{l}0.10^{* * * *} \\
(3.98)\end{array}$ & $\begin{array}{l}0.16^{* * *} \\
(4.20)\end{array}$ & $\begin{array}{l}0.10^{* * *} \\
(3.98)\end{array}$ & $\begin{array}{l}0.16^{* * *} \\
(4.20)\end{array}$ \\
\hline ENG 2 & $\begin{array}{l}0.17 * * * \\
(3.62)\end{array}$ & $\begin{array}{l}0.11^{*} \\
(1.62)\end{array}$ & $\begin{array}{l}0.17 * * * \\
(3.62)\end{array}$ & $\begin{array}{l}0.11^{*} \\
(1.62)\end{array}$ \\
\hline Distance & $\begin{array}{l}-0.93 * * * \\
(6.61)\end{array}$ & $\begin{array}{l}-0.99 * * * \\
(5.01)\end{array}$ & $\begin{array}{l}-0.93 * * * \\
(6.61)\end{array}$ & $\begin{array}{l}-0.99 * * * \\
(5.01)\end{array}$ \\
\hline Reference Price & $\begin{array}{l}-0.84 * * * \\
(3.53)\end{array}$ & $\begin{array}{l}0.32 \\
(0.88)\end{array}$ & $\begin{array}{l}-0.84 * * * \\
(3.53)\end{array}$ & $\begin{array}{l}0.32 \\
(0.88)\end{array}$ \\
\hline Differentiated & $\begin{array}{l}0.59^{*} \\
(1.80)\end{array}$ & $\begin{array}{l}-0.94 \\
(1.57)\end{array}$ & $\begin{array}{l}0.59^{*} \\
(1.80)\end{array}$ & $\begin{array}{l}-0.94 \\
(1.57)\end{array}$ \\
\hline Con & $\begin{array}{l}3.02 \\
(1.01)\end{array}$ & $\begin{array}{l}-1.36 \\
(0.29)\end{array}$ & $\begin{array}{l}9.77 * * * \\
(5.75)\end{array}$ & $\begin{array}{l}6.72 * * * \\
(2.64)\end{array}$ \\
\hline $\mathrm{N}$ & 536 & 338 & 536 & 338 \\
\hline $\mathrm{R}^{2}$ & 0.35 & 0.40 & 0.35 & 0.40 \\
\hline
\end{tabular}

Goods that are traded on an organized exchange are captured in the constant term. All standard errors were adjusted using the STATA Robust option. t-statistics are in parentheses and *,**, and $* * *$ represent significance at the $10 \%, 5 \%$ and $1 \%$ level, respectively. The dependent variable is the logarithm of the average of 1994, 1995, and 1996 for either U.S. exports or U.S. imports. GDPUS*GDP equals the logarithm of the product of U.S. GDP and the foreign GDP. The POPUS*POP is defined analogously to GDPUS*GDP. Eng $1=$ the logarithm of the proportion who speak English as a first language and Eng $2=$ the logarithm of the proportion who speak English as a second language. All variables, except Reference Price and Differentiated are in logarithms. See the text for a description of these product groups. 
Appendix Table A

\section{Country List}

(per cent)

\begin{tabular}{|c|c|c|}
\hline & Eng 1 & Eng2 \\
\hline Australia & 84.9 & 11.6 \\
\hline Banladesh & 0 & 2.6 \\
\hline The Bahamas & 90.6 & 9.1 \\
\hline Belize & 62.5 & 13.9 \\
\hline Barbados & 100 & 0 \\
\hline Canada & 66.9 & 20.4 \\
\hline Cameroon & 0 & 49.9 \\
\hline Fiji & 0.6 & 20.2 \\
\hline United Kingdom & 97.3 & 1.9 \\
\hline Ghana & 0 & 70.0 \\
\hline Guyana & 90.9 & 3.9 \\
\hline Hong Kong, China & 2.0 & 30.0 \\
\hline India & 0.1 & 3.9 \\
\hline Ireland & 94.7 & 5.3 \\
\hline Jamaica & 95.2 & 2.0 \\
\hline Kenya & 9.0 & 0.1 \\
\hline Sri Lanka & 0.1 & 10.2 \\
\hline Malta & 2.2 & 23.2 \\
\hline Mauritius & 0.1 & 14.8 \\
\hline Malaysia & 1.9 & 30.0 \\
\hline Nigeria & 0 & 45.1 \\
\hline Nepal & 29.5 & 16.9 \\
\hline New Zealand & 95.2 & 4.2 \\
\hline Pakistan & 0 & 11.4 \\
\hline Philippines & 0.1 & 52.0 \\
\hline Singapore & 10.0 & 35.0 \\
\hline Seychelles & 2.7 & 14.7 \\
\hline Trinidad Tobago & 94.9 & 0.1 \\
\hline Tanzania & 10.7 & 0.1 \\
\hline Uganda & 0 & 10.7 \\
\hline South Africa & 8.7 & 24.1 \\
\hline Zambia & \multicolumn{2}{|c|}{0.5} \\
\hline Zimbabwe & 2.2 & 29.3 \\
\hline
\end{tabular}




\section{References}

Anderson, James (1979) "A Theoretical Foundation for the Gravity Equation" American Economic Review 69:1 March pp. 106-116.

Baier, Scott L. and Jeffrey H. Bergstrand (2001) "The Growth of World Trade: Tariffs, Transport Costs, and Income Inequality" Journal of International Economics 53:1 pp. 1-27.

Bergstrand, Jeffrey H. (1989) "The Generalized Gravity Equation, Monopolistic Competition, and the Factor Proportions Theory of International Trade" Review of Economics and Statistics 71:1 February pp. 143-153.

Bergstrand, Jeffrey H. (1985) "The Gravity Equation in International trade: some Microeconomic Foundations and Empirical Evidence" Review of Economics and Statistics 67:4 pp. 474-481.

Bergstrand, Jeffrey H. (1990) "The Heckscher-Ohlin-Samuelson Model, The Linder Hypothesis and the Determinants of Bilateral Intra-Industry Trade" The Economic Journal 100 December. pp. 1216-1229.

Boisso, Dale and Michael Ferantino (1997) "Economic Distance, Cultural Distance, and Openness $\quad$ in International Trade: Empirical Puzzles" Journal of Economic Integration 12:4 pp. $456-484$.

Cheng, I-Hui and Howard J. Wall (2001) "Controlling for Heterogeneity in Gravity Models of Trade" Federal Reserve Bank of St. Louis Working Paper 1999-010B March.

Crystal, David (1997) English as a Global Language. Cambridge: Cambridge University Press. Chiswick, Barry and Paul Miller (1998) "English Language Fluency Among Immigrants in the United States" Research in Labor Economics 17 pp. 151-200. 
Dunlevey, James A. and William K. Hutchinson (1999) "The Impact of Immigration on American Import Trade in the Late Nineteenth and Early Twentieth Centuries" Journal of Economic History, December, 1999. pp. 1043-1062.

Evenett, Simon J. "(2002) "Does Gravity Reassert Itself? The Removal of Economic Sanctions and Bilateral Trade Flows" Scottish Journal of Political Economy November, forthcoming.

Feenstra, Robert C. (2002) "Monopolistic Competition and the Gravity Equation: Consistent Methods for Estimation" Scottish Journal of Political Economy November, forthcoming..

Feenstra, Robert C., James Markusen and Andrew Rose (1998) "Understanding the Home Market Effect and the Gravity Equation: The Role of Differentiated Goods" NBER Working Paper \# 6804.

Frankel, Jeffrey A., Erenesto Stein and Shang-Jin Wei (1998) "Why Do Countries Seek Regional Trade Agreements?" in Jeffrey A. Frankel (ed.) The Regionalization of the World Economy Chicago: University of Chicago Press. pp. 91-113.

Gould, David (1994) "Immigrant Links to Home Country: Empirical Implications for U.S. Bilateral Trade Flows" Review of Economics and Statistics 76:2 pp. 302-316.

Grossman, Gene (1998) "Comment" in Jeffrey A. Frankel (ed.) The Regionalization of the World Economy Chicago: University of Chicago Press, pp. 29-31.

Head, Keith and John Ries (1998) "Immigration and Trade Creation: Econometric Evidence from Canada" Canadian Journal of Economics 31:1 February pp. 47-62. Head, Keith, John Ries, and Donald Wagner (2002) "Immigration and the Trade of Provinces" Scottish Journal of Political Economy November. 
Helpman, Elhanan and Paul Krugman (1985) Market Structure and Foreign Trade. Cambridge, Massachusetts: MIT Press.

Hutchinson, William K. (2001) "Linguistic Distance as a Determinant of U.S. Bilateral Trade" Vanderbilt University Department of Economics Working Paper \# 01-W-25.

Hutchinson, William K. and James A. Dunlevy (2001) "Pro-Trade Effect of Immigration on American Exports During the Classical Liberal Period" Vanderbilt University

Department of Economics Working Paper \# 01-W30.

Linnemann, Hans (1966) An Econometric Study of International Trade Flows Amsterdam: North-Holland Publishers.

Loungani, Prakash, Ashoka Mody, and Assaf Razin (2002) "The Global Disconnect:

Transactional Distance and Scale Economies" Scottish Journal of Political Economy November, forthcoming.

Matyas, Laszlo (1997) "Proper Econometric Specifications of the Gravity Model" World Economy 20:3 May pp. 363-368.

Matyas, Laszlo (1998) "The Gravity Model: Some Econometric Considerations" World

Economy 21:3 May pp. 397-401.

Pakko, Michael and Howard J. Wall (2001) "Reconsidering the Trade Creating Effects of a Currency Union" Federal Reserve Bank of St. Louis $\quad$ Review 83:6

September/October pp. 37-45.

Portes, Richard, Helen Rey and Yonghyup Oh (2001) "Information and Capital Flows: The Determinants of Transactions in Financial Assets" European Economic Review 45 pp. 783-796. 
Rauch, James (1999) "Networks Versus Markets in International Trade" Journal of International Economics 48:1 June pp. 7-35.

Rauch, James and Vitor Trindade (2002) "Ethnic Chinese Networks in International Trade" Review of Economics and Statistics 84:1 pp. 116-130.

Tinbergen, Jan (1962) "An Analysis of World Trade Flows" in Jan Tinbergen (ed.) Shaping the World Economy New York: The Twentieth Century Fund. 